\title{
Nutrient enrichment, grazer identity, and their effects on epiphytic algal assemblages: field experiments in subtropical turtlegrass Thalassia testudinum meadows
}

\author{
Lesley P. Baggett ${ }^{1,2, *}$, Kenneth L. Heck Jr. ${ }^{1,2}$, Thomas A. Frankovich ${ }^{3}$, \\ Anna R. Armitage ${ }^{3,4}$, James W. Fourqurean ${ }^{3}$ \\ ${ }^{1}$ Dauphin Island Sea Lab, 101 Bienville Boulevard, Dauphin Island, Alabama 36528, USA \\ ${ }^{2}$ Department of Marine Science, University of South Alabama, Mobile, Alabama 36688, USA \\ ${ }^{3}$ Marine Science Program, Department of Biological Sciences and Southeast Environmental Research Center, \\ Florida International University, 3000 NE 151st Street, North Miami, Florida 33181, USA \\ ${ }^{4}$ Department of Marine Biology, Texas A\&M University at Galveston, PO Box 1675, Galveston, Texas 77553, USA
}

\begin{abstract}
We tested the relative importance of top-down and bottom-up effects by experimentally evaluating the combined and separate effects of nutrient availability and grazer species composition on epiphyte communities and seagrass condition in Florida Bay. Although we succeeded in substantially enriching our experimental cylinders, as indicated by elevated nitrogen concentrations in epiphytes and seagrass leaves, we did not observe any major increases in epiphyte biomass or major loss of Thalassia testudinum by algal overgrowth. Additionally, we did not detect any strong grazer effects and found very few significant nutrient-grazer interactions. While this might suggest that there was no important differential response to nutrients by individual grazer species or by various combinations of grazers, our results were complicated by the lack of significant differences between control and grazer treatments, and as such, these results are best explained by the presence of unwanted amphipod grazers (mean $=471$ ind $\mathrm{m}^{-2}$ ) in the control cylinders. Our estimates of grazing rates and epiphyte productivities indicate that amphipods in the control cylinders could have lowered epiphyte biomass to the same level that the experimental grazers did, thus effectively transforming the control treatments into grazer treatments. If so, our experiments suggest that the effects of invertebrate grazing (and those of amphipods alone) were stronger than the effects of nutrient enrichment on epiphytic algae, and that it does not require a large density of grazers to control epiphyte biomass even when nutrient loading rates are substantially elevated.
\end{abstract}

KEY WORDS: Nutrient enrichment · Grazing · Seagrass · Epiphytes · Gastropods · Caridean shrimp · Hermit crab

\section{INTRODUCTION}

Seagrass loss in both temperate and tropical latitudes has accelerated in the recent past, with reductions nearly 10 times greater in the early 2000s than in the 1960s (Orth et al. 2006). Waycott et al. (2009) recently estimated that global seagrass loss has been occurring at a rate of $110 \mathrm{~km}^{2} \mathrm{yr}^{-1}$ since 1980 and that the rate of seagrass loss has increased to a median of $7 \% \mathrm{yr}^{-1}$ since 1990 , up from a median loss rate of $0.9 \%$ $\mathrm{yr}^{-1}$ before 1940. Much of this loss can be attributed to the direct and indirect effects of anthropogenic activities (Waycott et al. 2009). The increasingly widespread nature of these losses, combined with the growing effects of anthropogenic activities in coastal environments, have spurred research on the processes that 
control the distribution and abundance of seagrasses. Traditional thought has been that bottom-up factors are of primary importance in controlling the structure of seagrass ecosystems, and this idea has been supported by numerous studies (e.g. Duarte 1995, Hauxwell et al. 2001). As such, coastal nutrient enrichment has been cited as a major cause of seagrass decline, with the primary mechanism being light attenuation brought about by the stimulation of epiphytic, macroalgal, and phytoplanktonic growth (see Burkholder et al. 2007 for review).

More recently, evidence supporting top-down control has mounted, as many studies have demonstrated that grazers can have strong negative effects on macroalgae (e.g. Duffy 1990, Duffy \& Hay 2000, Nielsen 2003) and phytoplankton (e.g. Officer et al. 1982, Caraco et al. 1997), as well as epiphytes present on seagrass blades. Early studies by Howard (1982), van Montfrans et al. (1982), Hootsmans \& Vermaat (1985), and Howard \& Short (1986) demonstrated the ability of consumers to reduce the biomass of epiphytes present on seagrass blades and noted the potential for grazers to influence seagrass health. Later studies confirmed the ability of both vertebrate (Gacia et al. 1999, Heck et al. 2000) and invertebrate (Philippart 1995, Jernakoff \& Nielsen 1997, Fong et al. 2000) grazers to positively affect seagrass health by the removal of epiphytes. In their discussion of the importance of topdown forces in shallow benthic ecosystems, Heck \& Valentine (2007) point out that most studies on eutrophication were performed long after the overfishing of large consumers had occurred and that the removal of these consumers 'can trigger indirect effects that result in altered species composition and abundance at several trophic levels, and can be very similar to those reported to result from eutrophication.'

Although many studies have examined the separate effects of nutrient enrichment and grazing on epiphytic algae in seagrass ecosystems, fewer have examined these 2 factors concurrently, as evidenced by the relative lack of such experiments in recent meta-data analyses by Hughes et al. (2004) and Burkepile \& Hay (2006). After finding that the positive effects of epiphyte grazers were comparable in magnitude to the negative impacts of water column nutrient enrichments,' Hughes et al. (2004) emphasized the importance of the joint manipulation of nutrients and grazers in elucidating the relative roles of eutrophication and overfishing in the decline of seagrass. The importance of understanding these roles was echoed by Burkepile \& Hay (2006).

In this study, we quantified the separate and combined effects of nutrient enrichment and different combinations of epiphyte grazers on the seagrass Thalassia testudinum Banks ex König in a subtropical setting. To explore a broader range of grazing effects and to better replicate an entire assemblage of seagrass bed mesograzers, we used grazers with different morphologies and feeding styles. Specifically, we addressed the following questions: (1) Does nutrient enrichment lead to elevated epiphyte biomass on T. testudinum leaves and a subsequent decrease in T. testudinum biomass (i.e. do bottom-up effects dominate), (2) Can invertebrate grazers prevent elevated epiphyte biomass from accumulating on $T$. testudinum leaves as a result of nutrient enrichment, and thus lessen the negative effects of enrichment on $T$. testudinum meadows (i.e. do top-down effects dominate)? And if so, are certain grazers, or combinations of grazers, more effective than others?

\section{MATERIALS AND METHODS}

Study sites. Experiments were conducted in Florida Bay, a shallow estuarine system dominated by Thalassia testudinum (turtlegrass) that separates the peninsula of Florida from the Florida Keys. Although Florida Bay is historically oligotrophic, instances of algal blooms have been observed since the late 1980s. To obtain site-season replication, experiments were performed near Bob Allen Keys in the eastern part of the bay during the spring of $2003\left(25^{\circ} 01^{\prime} 51.6^{\prime \prime} \mathrm{N}, 80^{\circ} 40^{\prime} 19.2^{\prime \prime} \mathrm{W}\right)$ and 2004 $\left(25^{\circ} 01^{\prime} 50.28^{\prime \prime}\right.$ N, $\left.80^{\circ} 41^{\prime} 14.1^{\prime \prime} \mathrm{W}\right)$ and near Peterson Key in the western part of the bay during the fall of 2003 $\left(24^{\circ} 54^{\prime} 48^{\prime \prime} \mathrm{N}, 80^{\circ} 44^{\prime} 30^{\prime \prime} \mathrm{W}\right)$ and $2004\left(24^{\circ} 55^{\prime} 9.18^{\prime \prime} \mathrm{N}\right.$, $80^{\circ} 44^{\prime} 38.88^{\prime \prime}$ W) (Fig. 1). The eastern sites were located in an area of Florida Bay that is severely phosphorus (P)-limited (Fourqurean \& Zieman 2002, Armitage et al. 2005), while the western sites were located in an area that may experience both nitrogen $(\mathrm{N})$ - and P-limitation (Armitage et al. 2005).

Experimental design. We used in situ mesocosms deployed in shallow seagrass beds to allow us to measure the combined and separate effects of nutrient availability and grazer composition on epiphyte communities and seagrass condition. Both nutrients and grazers can affect seagrass growth rates and aboveand belowground biomass; however, Thalassia testudinum leaf emergence rates on short shoots (SS) are relatively slow. For example, Peterson \& Fourqurean (2001) found the mean leaf emergence rate of T. testudinum in the Florida Keys to be $0.0295 \pm 0.0128$ leaves $\mathrm{SS}^{-1} \mathrm{~d}^{-1}$. Thus, it is unlikely we would observe increases in seagrass biomass during our experiments. Nutrients can increase seagrass leaf loss rate via epiphyte shading (Philippart 1995), leading to a decrease in aboveground seagrass biomass. It is for this reason that we used T. testudinum aboveground biomass as the response variable to assess nutrient (bottom-up) 
and grazer (top-down) effects on seagrass condition. Epiphyte biomass and algal pigment concentrations (epiphyte composition) were used as response variables to assess nutrient and grazer effects on epiphyte communities. T. testudinum and epiphyte C:N:P ratios were used to determine the stoichiometric response to nutrient enrichment, if in fact it occurred, during the experiments. The experiments were of a $2 \times 4$ factorial design (except for a $2 \times 8$ factorial design in fall 2004), with 2 nutrient treatments (ambient and enriched), and 4 grazer treatments in spring 2003, fall 2003, and spring 2004 and 8 grazer treatments in fall 2004.

Experimental mesocosms consisted of transparent cylindrical enclosures $(0.61 \mathrm{~m}$ tall, $0.30 \mathrm{~m}$ internal diameter, $0.07 \mathrm{~m}^{2}$ footprint, $0.04 \mathrm{~m}^{3}$ volume) deployed in beds of Thalassia testudinum at a water depth of approximately $0.40 \mathrm{~m}$. The cylinders were pushed approximately $10 \mathrm{~cm}$ into the sediment and anchored using metal reinforc-

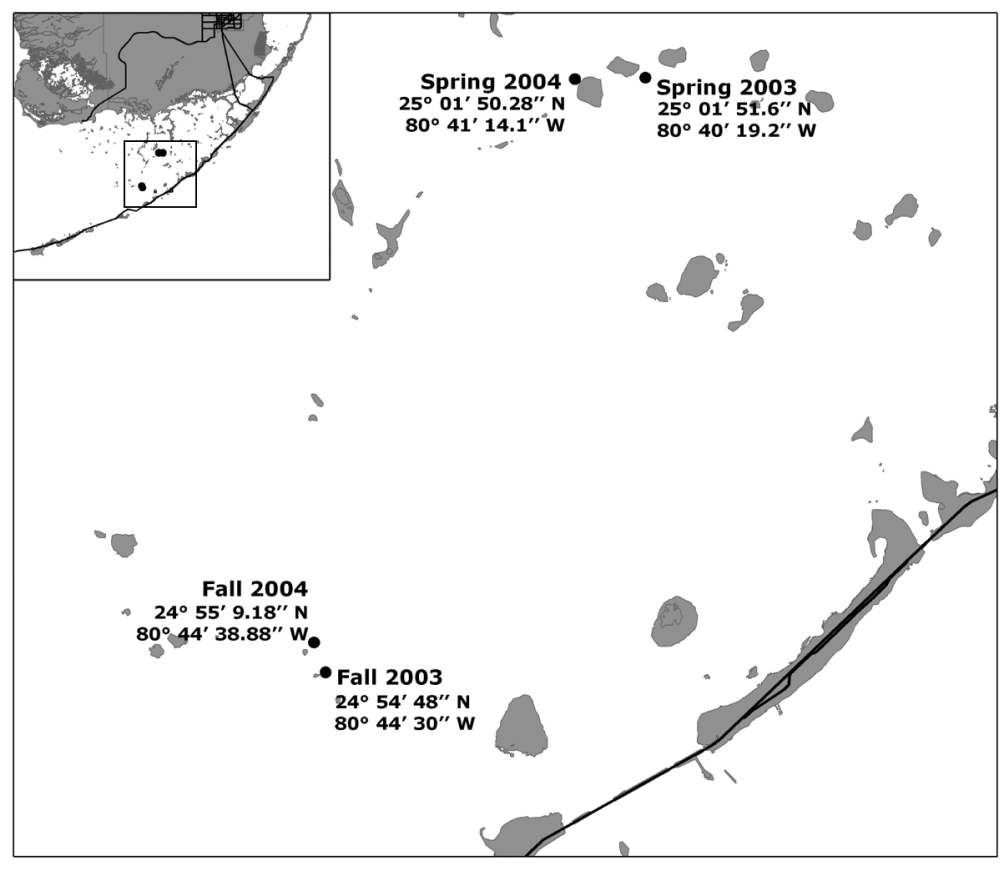

Fig. 1. Location of study sites in Florida Bay, Florida, USA ing rods and rope guidelines. The cylinders were covered with mesh tops $(0.50 \mathrm{~mm})$ to prevent grazers from escaping and disturbance by birds. Six small holes ( $5 \mathrm{~cm}$ diameter) spaced at regular intervals in the cylinder walls and covered with $0.50 \mathrm{~mm}$ mesh allowed water exchange between the cylinders and the outside environment. Cylinders were approximately threequarters submerged when deployed and likely remained so throughout most of the experiment because of the relative lack of lunar tides in central Florida Bay (Turney \& Perkins 1972, Holmquist et al. 1989, Fourqurean \& Robblee 1999). However, changes in wind direction due to storm fronts can override lunar tides throughout Florida Bay (Fourqurean \& Robblee 1999) and, therefore, the cylinders may have been periodically further exposed or submerged during the course of the experiment.

Nutrients were added to enriched treatment cylinders by suspending a perforated PVC tube filled with the controlled-release fertilizer Osmocote ${ }^{\mathrm{TM}}$. On the basis of previous Osmocote ${ }^{\mathrm{TM}}$ dissolution experiments (Heck et al. 2000, Heck et al. 2006), the PVC tubes were loaded with $250 \mathrm{~g}$ of Osmocote $^{\mathrm{TM}}$ (N:P molar ratio $=19: 6$ ), which was expected to achieve nutrient concentrations that were as much as 100 times greater than ambient conditions. A study by Heck et al. (unpubl.) in Big Lagoon, Florida, showed that nutrient saturation of epiphytes and seagrass was achieved at nutrient levels that were approximately 10 times those of ambient conditions, and that there was no significant difference in the C:N:P ratios of Thalassia tes-

tudinum leaves between $10 \times$ and $100 \times$ treatments. For this study, the $100 \times$ treatment was chosen to ensure maximum nutrient loading throughout the duration of the experiment and to ensure that a nutrient effect would be observed if, in fact, there was one. Ambient nutrient treatments contained similar PVC tubes without Osmocote ${ }^{\mathrm{TM}}$. Osmocote ${ }^{\mathrm{TM}}$-containing PVC tubes were replaced halfway into the experiment to ensure constant nutrient loading (see Heck et al. 2000 for Osmocote ${ }^{\mathrm{TM}}$ dissolution rates). Osmocote ${ }^{\mathrm{TM}}$ remaining in the tubes at the halfway point and at the end of the experiment was dried and weighed in order to estimate average nitrogen and phosphorus loading rates during the course of the experiment.

Several invertebrate species feed on epiphytes of Thalassia testudinum blades in Florida Bay, and we utilized 3 different types of invertebrate epiphyte grazers to better understand the effects of grazer identity on epiphyte accumulation and composition. Grazers used were based on seasonal availability and their high relative abundance in $T$. testudinum beds (Robblee \& Daniels 2003, Frankovich \& Zieman 2005, Gil et al. 2006) and were collected in Florida Bay by hand. In spring 2003, fall 2003, and spring 2004, the gastropod Turbo castanea Gmelin and a combination of the caridean shrimp Thor manningi Chace, T. floridanus Kingsley, and Hippolyte spp., which could not be reliably identified to species level while alive, were used in 4 grazer treatments (zero grazers, T. castanea only, caridean shrimp only, and T. castanea + caridean shrimp). In fall 2004, the hermit crab Paguristes tortu- 
gae Schmitt was added as a grazer treatment in addition to the caridean shrimp and T. castanea, allowing 8 grazer treatments (zero grazers, T. castanea only, caridean shrimp only, $P$. tortugae only, T. castanea + caridean shrimp, $T$. castanea $+P$. tortugae, caridean shrimp $+P$. tortugae, and $T$. castanea + caridean shrimp $+P$. tortugae)

Observed field densities of these grazers range from an average of 6.7 to 27.5 ind. $\mathrm{m}^{-2}$ (Frankovich \& Zieman 2005) for Turbo castanea, an average of 15 to 130 ind. $\mathrm{m}^{-2}$ for Thor spp. (Robblee \& Daniels 2003), to an average of 1 to 12 ind. $\mathrm{m}^{-2}$ for Paguristes tortugae (Gil et al. 2006). In our experiments, we used densities that were higher than these observed densities for 2 reasons: (1) to offset grazer mortality and potentially lessened effective density of grazers due to grazing on epiphytes growing on the inner surfaces of our experimental cylinders, and (2) to ensure that we would see a grazer effect if, in fact, there was one. In treatments containing gastropods alone or in combination with another grazer, 5 T. castanea (71 ind. $\mathrm{m}^{-2}$ ) were added. Seventy caridean shrimp (1000 ind $\mathrm{m}^{-2}$ ) were added to treatments containing shrimp alone or in combination with another grazer. Five $P$. tortugae $\left(71\right.$ ind. $\mathrm{m}^{-2}$ ) were added to treatments containing hermit crabs alone or in combination with another grazer (see Table 1). While we were unable to determine the reproductive status of $T$. castanea and $P$. tortugae before adding them to the cylinders, care was taken to avoid using gravid caridean shrimp in the experiments.

Four replicates of each nutrient-grazer treatment combination were randomly assigned to the experimental cylinders. An experimental duration of 4 wk was chosen on the basis of previous studies that have demonstrated that small invertebrate grazers can produce considerable changes in algal biomass in as little

Table 1. Grazer treatments. Control = no grazers; $G=$ gastropod (Turbo castanea); $\mathrm{G}+\mathrm{S}=$ gastropod $+\operatorname{shrimp}($ T . castanea + caridean shrimp); $\mathrm{G}+\mathrm{H}=$ gastropod + hermit crab (T. castanea + Paguristes tortugae) $; \mathrm{G}+\mathrm{H}+\mathrm{S}=$ gastropod + hermit crab $+\operatorname{shrimp}(T$. castanea $+P$. tortugae + caridean shrimp $) ;$ $\mathrm{S}=\operatorname{shrimp}$ (caridean shrimp); $\mathrm{S}+\mathrm{H}=$ shrimp + hermit crab (caridean shrimp $+P$. tortugae) $\mathrm{H}=$ hermit crab (P. tortugae)

\begin{tabular}{|lccc|}
\hline $\begin{array}{l}\text { Grazer } \\
\text { treatment }\end{array}$ & $\begin{array}{c}\text { No. of } \\
\text { T. castanea }\end{array}$ & $\begin{array}{c}\text { No. of caridean } \\
\text { shrimp }\end{array}$ & $\begin{array}{c}\text { No. of } \\
\text { P. tortugae }\end{array}$ \\
\hline Control & 0 & 0 & 0 \\
G & 5 & 0 & 0 \\
G + S & 5 & 70 & 0 \\
G + H & 5 & 0 & 5 \\
G + H + S & 5 & 70 & 5 \\
S & 0 & 70 & 0 \\
S + H & 0 & 70 & 5 \\
H & 0 & 0 & 5 \\
\hline
\end{tabular}

as 1 to 2 wk (Duffy \& Hay 2000, Ruesink 2000, Duffy \& Harvilicz 2001) and the relatively short lifespan (4 to $5 \mathrm{mo}$ ) of Thor floridanus, a large component of our caridean shrimp treatments. Additionally, we limited the experimental duration to $4 \mathrm{wk}$ to lessen artifacts such as fouling and shading that grow worse the longer the cylinders are deployed. Before experimental grazers were added, all cylinders were cleared of existing grazers using a suction sampling technique that was modified from that originally used by Orth \& van Montfrans (1987).

One of the greatest potential artifacts associated with caging experiments is a change in light regime, and we evaluated the possibility of this occurring in the cylinders. During spring 2004, measurements of photosynthetically active radiation (PAR) were taken with a LI-COR 4 pi Underwater Quantum Sensor outside and inside of 10 randomly selected nutrient enriched cylinders and 10 randomly selected ambient cylinders at the end of the experiments to quantify the amount of light reduction caused by the cylinders, mesh tops, and any fouling that may have occurred during the course of the experiments.

The experimental cylinders were designed to restrict water flow to enable high nutrient loading rates, while still allowing enough water exchange to prevent anoxia within the cylinders. We quantified the relative amount of water flow restriction that occurred by measuring plaster dissolution rates (Doty 1971). In both the spring and fall of 2004, we deployed 6 plaster balls within and 6 plaster balls outside experimental cylinders placed within the study sites. Before deployment, the initial weights of the plaster balls were taken. The plaster balls were then suspended at a depth of approximately $0.3 \mathrm{~m}$ on wooden dowels anchored in the sediment. In fall 2004 the plaster balls were in the water for $24 \mathrm{~h}$, and in spring 2004, the plaster balls were in the water for $48 \mathrm{~h}$, because of high winds that prevented us from returning to the site after $24 \mathrm{~h}$. After the plaster balls were collected, they were dried in a drying oven at $80^{\circ} \mathrm{C}$ for $1 \mathrm{wk}$ and weighed. These weights were then compared to the initial weights, and an average dissolution rate was determined.

Upon termination of the experiment, the cylinders were suction sampled for $1 \mathrm{~min}$ to remove experimental grazers and any other organisms that may have entered or remained in the cylinders during the course of the experiment. A core sample (area $=0.00442 \mathrm{~m}^{2}$ ) was taken from the center of each cylinder to determine aboveground seagrass biomass. Fifteen additional seagrass shoots and their epiphytes were collected from each cylinder to be analyzed for seagrass and epiphyte $\mathrm{C}: \mathrm{N}: \mathrm{P}$ ratios, epiphyte biomass, and the relative abundance of algal pigments in the epiphytes via high performance liquid chromatography (HPLC). 
All samples were transported on ice to the lab and frozen. Suction samples were sorted, all experimental grazers were enumerated, and the percent recovered of the original amount added was determined (hereafter referred to as 'percent recovery'). Other potential grazers present in the samples were also counted and identified to the lowest practicable taxonomic level. This allowed us to determine the efficacy of the experimental cylinders in maintaining the grazer treatments.

To determine aboveground Thalassia testudinum biomass, shoots from core samples were rinsed to remove sediments, and the aboveground portion of the shoots was separated from the rhizomes. The shoots were then dried at $80^{\circ} \mathrm{C}$ for at least $24 \mathrm{~h}$ to determine dry weight (DW).

When measuring epiphyte biomass, composition, and C:N:P ratios, we standardized our measurements, since the amount of epiphytes per leaf can vary greatly between different leaves on a shoot. We took epiphyte samples from the oldest leaves on the shoots, because T. testudinum leaf turnover rate is quite low and we wanted to ensure that the leaves we used were present throughout the experiment and had, therefore, received the full effect of the treatments. All shoots used in the determination of epiphyte biomass, composition, and $\mathrm{C}: \mathrm{N}: \mathrm{P}$ were rinsed prior to scraping to remove any sediment. To determine epiphyte biomass, epiphytes from the oldest leaf of $5 \mathrm{~T}$. testudinum shoots were removed by scraping the leaves with a razor blade. The length and width of these leaves were measured to obtain leaf surface area. These epiphytes and leaves were placed in separate pre-weighed pans and then dried at $80^{\circ} \mathrm{C}$ for at least $24 \mathrm{~h}$ to determine DW.

The oldest leaves of 5 more Thalassia testudinum shoots were scraped clean of epiphytes, and their leaf surface area was obtained. The DW of these leaves was determined, and the relative abundance of algal pigments within the scraped epiphytes was determined by HPLC, following the methods of Wright et al. (1991). Epiphyte composition was assessed by looking at concentrations of the following pigments: fucoxanthin, zeaxanthin, chlorophyll a (chl a), and chlorophyll $b(\mathrm{chl} b$ ). While chl $a$ is a pigment found in many functional groups and is often used as a measure of total epiphyte abundance, fucoxanthin is indicative of diatoms, chl $b$ is indicative of chlorophytes (Paerl et al. 2003), and zeaxanthin is indicative of a cyanobacteria/ red algae complex (Jeffrey et al. 1997, Armitage et al. 2006).

To determine the C:N:P ratios of epiphytes, epiphytes were scraped from the oldest leaf of the remaining 5 Thalassia testudinum shoots, dried in an oven for $24 \mathrm{~h}$ at $80^{\circ} \mathrm{C}$, and ground to a homogenous powder using a mortar and pestle. To determine the C:N:P ratios of $T$. testudinum, the youngest leaf of each shoot was scraped clean of epiphytes, placed in a pan and dried in a $80^{\circ} \mathrm{C}$ drying oven for $24 \mathrm{~h}$, and ground to a homogenous powder using a mortar and pestle. Following the technique of Sharp (1974), nitrogen and carbon content of the epiphytes and leaves was measured with a Costech 4010 CNS Analyzer. Phosphorus content of the epiphytes and leaves was determined using the standard wet chemical technique of Solórzano \& Sharp (1980) and Fourqurean et al. (1992).

Data from the experiments were analyzed with a 2-way Analysis of Variance (ANOVA) using SPSS 11.0.0, where the 2 fixed factors were nutrient enrichment level and grazer treatment, and nutrient $\times$ grazer was the interaction term. When necessary, data were transformed using a $\log 10(\mathrm{x}+1)$ transformation to meet the assumptions of ANOVA. When significant differences $(p \leq 0.05)$ were detected and no interaction between nutrient enrichment level and grazer treatment was present, Bonferroni multiple comparison tests were performed.

\section{RESULTS}

Our original intent was to pool data from the 2 spring and the 2 fall experiments; however, a significant 'year' interaction prevented us from doing so. Thus, we discuss each of the 4 experiments separately. Although our factorial design allowed us to test both the separate and combined effects of nutrient enrichment and grazers, very few significant nutrient $\times$ grazer interactions were observed. All significant results are presented in Table 2 .

\section{Potential caging artifacts}

Post hoc analysis determined that PAR measurements outside the cylinders were significantly greater than those inside the ambient $(p<0.001)$ and enriched cylinders $(p<0.001)$, but that there was no significant difference between PAR measurements inside the ambient and enriched cylinders. The mean PAR outside the cylinders was $2727 \pm 103 \mu \mathrm{E} \mathrm{m}^{-2} \mathrm{~s}^{-1}$, and the mean PAR inside the ambient and enriched cylinders was $1149 \pm 103 \mu \mathrm{E} \mathrm{m} \mathrm{m}^{-2} \mathrm{~s}^{-1}$ and $1001 \pm 103 \mu \mathrm{E} \mathrm{m} \mathrm{m}^{-2} \mathrm{~s}^{-1}$, respectively. Since PAR measurements inside both ambient and enriched cylinders were well above the light saturation level of $630 \mu \mathrm{E} \mathrm{m}^{-2} \mathrm{~s}^{-1}$ for Thalassia testudinum and its epiphytes as reported by Capone et al. (1979), it seems unlikely that the light reduction caused by the cylinders negatively affected $T$. testudinum and epiphyte growth.

Plaster ball dissolution rates were significantly higher outside than inside the cylinders in spring 2004 
Table 2. Significant univariate results of 2-way ANOVAs testing nutrient and grazer effects

\begin{tabular}{|c|c|c|c|c|}
\hline $\begin{array}{c}\text { Variable } \\
\text { Season }\end{array}$ & Factor & $\mathrm{df}$ & F-ratio & $\mathrm{p}$ \\
\hline \multicolumn{5}{|c|}{ Epiphyte dry weight $\left(\mathrm{mg} \mathrm{cm}^{-2}\right)$} \\
\hline Spring 2004 & Nutrient & 1 & 7.46 & 0.013 \\
\hline \multicolumn{5}{|c|}{ Fucoxanthin $\left(\mu \mathrm{g} \mathrm{cm}^{-2}\right)$} \\
\hline Fall 2003 & Nutrient & 1 & $\begin{array}{l}8.99 \\
3.43\end{array}$ & 0.007 \\
\hline Fall 2004 & Grazer & 7 & 3.35 & 0.006 \\
\hline \multicolumn{5}{|c|}{ Zeaxanthin $\left(\mu \mathrm{g} \mathrm{cm}^{-2}\right)$} \\
\hline Spring 2004 & Nutrient & 1 & 17.43 & $<0.001$ \\
\hline Fall 2004 & Nutrient & 1 & 9.54 & 0.003 \\
\hline \multicolumn{5}{|c|}{ Chl $\boldsymbol{b}\left(\mu \mathrm{g} \mathrm{cm}^{-2}\right)$} \\
\hline \multirow[t]{2}{*}{ Fall 2003} & Nutrient & 1 & 11.56 & 0.003 \\
\hline & Nutrient $\times$ Grazer & 3 & 11.03 & $<0.001$ \\
\hline Spring 2004 & Nutrient & 1 & 16.65 & $<0.001$ \\
\hline Fall 2004 & Nutrient & 1 & 7.55 & 0.009 \\
\hline \multicolumn{5}{|c|}{ Chl $\boldsymbol{a}\left(\mu \mathrm{g} \mathrm{cm}^{-2}\right)$} \\
\hline Fall 2003 & Nutrient & 1 & 10.16 & 0.004 \\
\hline Spring 2004 & Nutrient & 1 & 29.49 & $<0.001$ \\
\hline \multicolumn{5}{|c|}{ Epiphyte C:N } \\
\hline Spring 2003 & Nutrient & 1 & 39.14 & $<0.001$ \\
\hline Spring 2004 & Nutrient $\times$ Grazer & 3 & 3.53 & 0.034 \\
\hline Fall 2004 & Nutrient & 1 & 12.42 & 0.001 \\
\hline \multicolumn{5}{|l|}{ Epiphyte C:P } \\
\hline Spring 2003 & Nutrient & 1 & 117.83 & $<0.001$ \\
\hline Fall 2003 & $\begin{array}{l}\text { Nutrient } \\
\text { Grazer }\end{array}$ & $\begin{array}{l}1 \\
3\end{array}$ & $\begin{array}{r}13.27 \\
7.36\end{array}$ & $\begin{array}{l}0.002 \\
0.003\end{array}$ \\
\hline Spring 2004 & $\begin{array}{c}\text { Nutrient } \\
\text { Nutrient } \times \text { Grazer }\end{array}$ & $\begin{array}{l}1 \\
3\end{array}$ & $\begin{array}{r}49.67 \\
3.35\end{array}$ & $\begin{array}{c}<0.001 \\
0.04\end{array}$ \\
\hline Fall 2004 & $\begin{array}{c}\text { Nutrient } \\
\text { Grazer }\end{array}$ & $\begin{array}{l}1 \\
7\end{array}$ & $\begin{array}{c}12.52 \\
3.4\end{array}$ & $\begin{array}{l}0.001 \\
0.005\end{array}$ \\
\hline \multicolumn{5}{|l|}{ Epiphyte N:P } \\
\hline Spring 2003 & Nutrient & 1 & 64.66 & $<0.001$ \\
\hline \multirow[t]{3}{*}{ Fall 2003} & Nutrient & 1 & 11.48 & 0.004 \\
\hline & Grazer & 3 & 4.43 & 0.019 \\
\hline & Nutrient $\times$ Grazer & 3 & 4.22 & 0.022 \\
\hline \multirow[t]{2}{*}{ Spring 2004} & Nutrient & 1 & 66.54 & $<0.001$ \\
\hline & Nutrient $\times$ Grazer & 3 & 8.7 & 0.001 \\
\hline Fall 2004 & Grazer & 7 & 3.09 & 0.009 \\
\hline \multicolumn{5}{|c|}{ Thalassia testudinum C:N } \\
\hline Spring 2003 & Nutrient & 1 & 20.33 & $<0.001$ \\
\hline \multirow[t]{2}{*}{ Spring 2004} & Nutrient & 1 & 7.68 & 0.012 \\
\hline & Grazer & 3 & 4.01 & 0.023 \\
\hline \multicolumn{5}{|c|}{ T. testudinum C:P } \\
\hline Spring 2003 & Nutrient & 1 & 262.73 & $<0.001$ \\
\hline \multirow[t]{2}{*}{ Spring 2004} & Nutrient & 1 & 41.26 & $<0.001$ \\
\hline & Grazer & 3 & 3.49 & 0.037 \\
\hline \multirow[t]{2}{*}{ Fall 2004} & Nutrient & 1 & 12.22 & 0.001 \\
\hline & Grazer & 7 & 3.87 & 0.002 \\
\hline \multicolumn{5}{|c|}{ T. testudinum N:P } \\
\hline Spring 2003 & Nutrient & 1 & 247.41 & $<0.001$ \\
\hline & Nutrient $\times$ Grazer & 3 & 2.282 & 0.102 \\
\hline Fall 2003 & Nutrient & 1 & 6.04 & 0.03 \\
\hline Spring 2004 & Nutrient & 1 & 34.19 & $<0.001$ \\
\hline Fall 2004 & Nutrient & 1 & 9.7 & 0.003 \\
\hline & Grazer & 7 & 2.64 & 0.023 \\
\hline
\end{tabular}

( $p=0.003$ ), but not in fall 2004. In spring 2004, the average dissolution rate was $155.06 \mathrm{~g} \mathrm{~d}^{-1}$ inside the cylinders and $176.93 \mathrm{~g} \mathrm{~d}^{-1}$ outside the cylinders. In fall 2004, the average dissolution rate was $166.14 \mathrm{~g} \mathrm{~d}^{-1}$ inside the cylinders and $188.38 \mathrm{~g} \mathrm{~d}^{-1}$ outside the cylinders. Mass mortality of the grazers or Thalassia testudinum was never observed in the cylinders during any of the experiments, indicating sufficient water exchange to prevent episodes of low oxygen concentration. In addition, there was only a $13.17 \%$ difference between dissolution rates inside and outside the cylinders in spring 2004, and only a $12.55 \%$ difference in dissolution rates in fall 2004.

\section{Maintenance of nutrient and grazer treatments}

In spring 2003, the average nutrient loading rate was $696 \mathrm{mmol} \mathrm{N} \mathrm{m}^{-2} \mathrm{~d}^{-1}$ and $105 \mathrm{mmol} \mathrm{P} \mathrm{m}^{-2} \mathrm{~d}^{-1}$. In fall 2003, the average nutrient loading rate increased to $949 \mathrm{mmol} \mathrm{N} \mathrm{m}{ }^{-2} \mathrm{~d}^{-1}$ and $141 \mathrm{mmol} \mathrm{P} \mathrm{m}^{-2} \mathrm{~d}^{-1}$. The average nutrient loading rates in 2004 were much lower, at $281 \mathrm{mmol} \mathrm{N} \mathrm{m}^{-2} \mathrm{~d}^{-1}$ and $41 \mathrm{mmol} \mathrm{P} \mathrm{m}^{-2} \mathrm{~d}^{-1}$ for spring 2004 and $454 \mathrm{mmol} \mathrm{N} \mathrm{m}^{-2} \mathrm{~d}^{-1}$ and $68 \mathrm{mmol} \mathrm{P} \mathrm{m}{ }^{-2} \mathrm{~d}^{-1}$ for fall 2004 .

Grazer recovery varied among treatments and between seasons (Table 3). The average recovery of Paguristes tortugae in fall 2004, the only season in which $P$. tortugae was used, was $63.57 \%$. Average

Table 3. Grazer recovery. $\mathrm{G}=$ gastropod (Turbo castanea); $\mathrm{S}=$ shrimp (caridean shrimp); $\mathrm{H}=$ hermit crab ( $P$. tortugae)

\begin{tabular}{|c|c|c|c|}
\hline \multirow{2}{*}{$\begin{array}{l}\text { Grazer } \\
\text { treatment }\end{array}$} & \multicolumn{3}{|c|}{ Average $\%$ recovery $( \pm 1 \mathrm{SD})$} \\
\hline & $\begin{array}{l}\text { Paguristes } \\
\text { tortugae }\end{array}$ & $\begin{array}{c}\text { Turbo } \\
\text { castanea }\end{array}$ & $\begin{array}{c}\text { Caridean } \\
\text { shrimp }\end{array}$ \\
\hline \multicolumn{4}{|c|}{ Spring 2003} \\
\hline \multicolumn{2}{|c|}{$\mathrm{G}$} & $64.44 \pm 11.44$ & \\
\hline \multicolumn{2}{|l|}{$\mathrm{S}$} & & $55.71 \pm 6.15$ \\
\hline \multicolumn{2}{|l|}{$\mathrm{G}+\mathrm{S}$} & $55.56 \pm 5.56$ & $25.40 \pm 2.70$ \\
\hline \multicolumn{4}{|l|}{ Fall 2003} \\
\hline \multicolumn{2}{|l|}{ G } & $10.00 \pm 6.83$ & \\
\hline \multicolumn{2}{|l|}{$\mathrm{S}$} & & $34.52 \pm 9.28$ \\
\hline \multicolumn{2}{|l|}{$\mathrm{G}+\mathrm{S}$} & $7.50 \pm 3.66$ & $46.61 \pm 5.68$ \\
\hline \multicolumn{4}{|c|}{ Spring 2004} \\
\hline \multicolumn{2}{|c|}{ G } & $35.56 \pm 9.88$ & \\
\hline \multicolumn{2}{|l|}{$\mathrm{S}$} & & $22.38 \pm 7.89$ \\
\hline \multicolumn{2}{|l|}{$G+S$} & $48.57 \pm 7.38$ & $16.33 \pm 3.94$ \\
\hline \multicolumn{4}{|l|}{ Fall 2004} \\
\hline $\mathrm{H}$ & $67.50 \pm 15.56$ & & \\
\hline G & & $60.00 \pm 11.34$ & \\
\hline $\mathrm{S}$ & & & $33.93 \pm 5.65$ \\
\hline $\mathrm{H}+\mathrm{G}$ & $54.29 \pm 19.38$ & $54.29 \pm 17.30$ & \\
\hline $\mathrm{H}+\mathrm{S}$ & $70.00 \pm 15.12$ & & $43.39 \pm 6.49$ \\
\hline $\mathrm{G}+\mathrm{S}$ & & $52.50 \pm 15.09$ & $30.54 \pm 7.65$ \\
\hline $\mathrm{H}+\mathrm{G}+\mathrm{S}$ & $62.50 \pm 16.66$ & $67.50 \pm 13.06$ & $32.68 \pm 7.89$ \\
\hline
\end{tabular}


Table 4. Unwanted grazers recovered from cylinders. Tallies represent the number of cylinders the unwanted grazer was found in out of the possible number of cylinders (e.g. amphipods were found in 29 out of 31 control cylinders). Averages represent the average numbers of unwanted grazers present in the cylinders in which they were found (cylinders with 0 unwanted grazers were not included in this average)

\begin{tabular}{|lcccrrr|}
\hline & $\begin{array}{c}\text { No. of control } \\
\text { treatments }\end{array}$ & $\begin{array}{c}\text { Average in } \\
\text { control treatments }\end{array}$ & $\begin{array}{c}\text { No. of grazer } \\
\text { treatments }\end{array}$ & $\begin{array}{c}\text { Average in } \\
\text { grazer treatments }\end{array}$ & $\begin{array}{c}\text { No. overall } \\
\text { Overall } \\
\text { average }\end{array}$ \\
\hline Amphipods & 29 of 31 & 32.8 & 125 of 127 & 39.9 & 154 of 158 \\
Hermit crabs & 7 of 31 & 1.3 & 27 of 127 & 1.6 & 34 of 158 & 1.6 \\
\hline
\end{tabular}

Turbo castanea recovery was $60.00 \%$ in spring 2003 , $8.75 \%$ in fall 2003, $42.07 \%$ in spring 2004, and $58.57 \%$ in fall 2004. Recovery of caridean shrimp was generally lower than that of the other grazers, averaging $40.56 \%$ in spring $2003,40.57 \%$ in fall 2003, $19.36 \%$ in spring 2004, and $35.14 \%$ in fall 2004.

When analyzing the suction samples, several unwanted grazers were found, including isopods, the gastropods Cerithium sp. and Modulus sp., amphipods, hermit crabs, and caridean shrimp. These grazers may have been present because they were missed during the initial suctioning of the cylinders, or because they entered the cylinders through the mesh screens as larvae. Although most unwanted grazers were present in only a few samples, and in very small numbers, hermit crabs and amphipods were found in numbers that merited attention (Table 4). Due to their frequent occurrence, amphipods were included as a covariate in spring 2003, fall 2003, and spring 2004 analyses, and both amphipods and hermit crabs were included as covariates in the fall 2004 analysis. The covariates were only included in the analyses of parameters in which it was possible that the grazing activities of amphipods and hermit crabs could have produced an effect (i.e. epiphyte algal pigments, epiphyte biomass, and epiphyte $\mathrm{C}: \mathrm{N}: \mathrm{P})$. When the covariates were not significant, they were removed from the model, and ANOVAs were run without them. Unwanted hermit crabs did not have any significant effects, and amphipods produced a significant effect in only one instance: epiphyte C:N in spring 2004 ( $\mathrm{p}=$ 0.009).

\section{Nutrient and grazer effects}

\section{Epiphyte biomass, composition, and C:N:P}

There were no consistent patterns in the effects of nutrients and grazers on epiphyte biomass. While there were a few significant nutrient and grazer effects on epiphyte composition, the only consistent pattern was that chl $b$ concentrations were greater in enriched than ambient treatments in all 3 experiments for which data exist (Fig. 2). There was a significant nutrient $\times$ grazer interaction present in fall 2003 for chl $b$ concentrations (Fig. 3, Table 2).

There were a few significant grazer effects on epiphyte $\mathrm{C}: \mathrm{N}: \mathrm{P}$, but there were no consistent patterns in the results; however, there were several significant nutrient effects on epiphyte C:N:P. Nutrient enrichment significantly decreased epiphyte C:N in spring 2003 and fall 2004 (Fig. 4), although there were no significant differences in epiphyte $\mathrm{C}: \mathrm{N}$ between nutrient treatments in fall 2003 and spring 2004. Nutrient enrichment effects on epiphyte C:P were more consistent, with nutrient enrichment significantly decreasing epiphyte C:P in all 4 experiments (Fig. 4). Nutrient enrichment significantly decreased epiphyte N:P in spring 2003, fall 2003, and spring 2004, but there was no significant difference in epiphyte N:P between ambient and enriched treatments in fall 2004 (Fig. 4). There was a significant nutrient $\times$ grazer interaction present for epiphyte C:N and C:P in spring 2004, and epiphyte N:P in fall 2003 and spring 2004 (Fig. 5, Table 2).

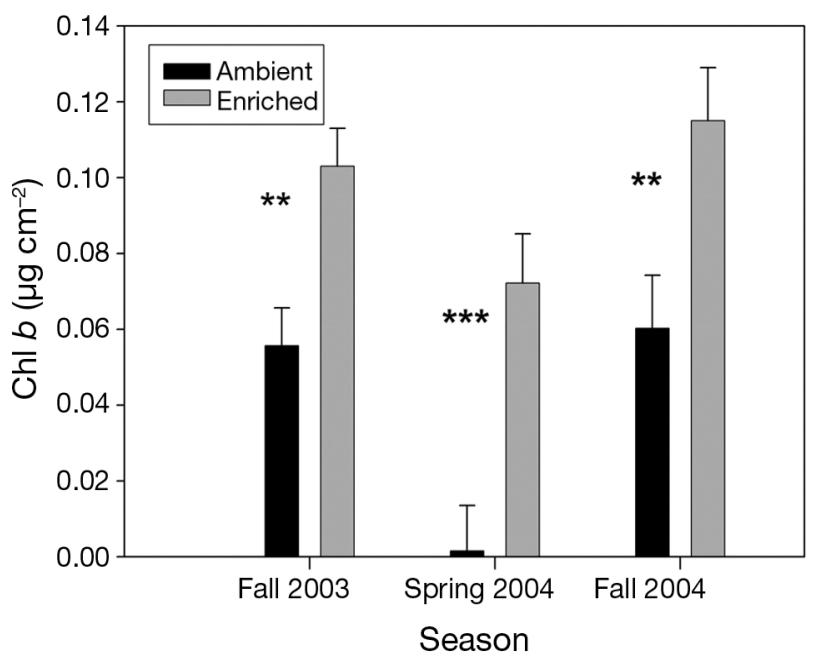

Fig. 2. Nutrient effects on chlorophyll $b$ concentrations (mean $\pm \mathrm{SE}$ ). Asterisks denote significant effect $\left({ }^{*} \mathrm{p} \leq 0.05\right.$, $* * \mathrm{p} \leq 0.01, * * * \mathrm{p} \leq 0.001)$ 


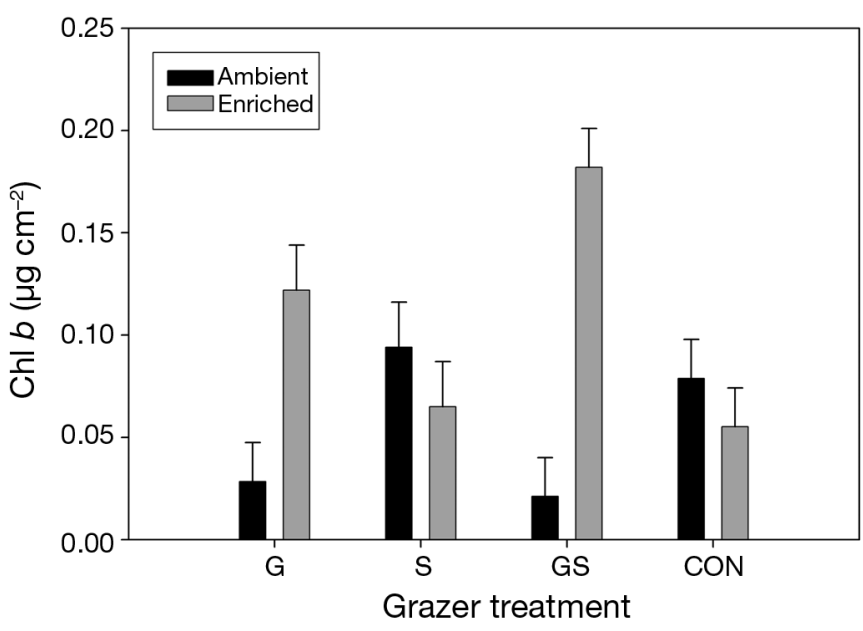

Fig. 3. Combined effects of nutrients and grazers on fall 2003 chlorophyll $b$ concentration. Grazer treatment abbreviations: $\mathrm{G}=$ Turbo castanea only, $\mathrm{S}=$ caridean shrimp only, GS =

T. castanea + caridean shrimp, $\mathrm{CON}=\mathrm{control} / \mathrm{no}$ grazers

\section{Thalassia testudinum biomass and C:N:P}

There were no consistent patterns in the effects of nutrients and grazers on Thalassia testudinum aboveground biomass. As with epiphyte $\mathrm{C}: \mathrm{N}: \mathrm{P}$, there were a few significant grazer effects on $T$. testudinum $\mathrm{C}: \mathrm{N}: \mathrm{P}$, but no consistent patterns in the results. Nutrient enrichment had significant effects on $T$. testudinum $\mathrm{C}: \mathrm{N}: \mathrm{P}$, with some patterns being clearer than others. $T$. testudinum $\mathrm{C}: \mathrm{N}$ was significantly lower in enriched than ambient treatments in spring 2003 and spring 2004 (Fig. 6), but there were no significant differences between nutrient treatments in fall 2003 and fall 2004. Nutrient effects on $T$. testudinum C:P were more consistent, with T. testudinum C:P significantly lower in enriched than ambient treatments in spring 2003, spring 2004, and fall 2004 (but not in fall 2003) (Fig. 6). T. testudinum N:P was the most consistent, with significantly lower values in enriched than in ambient treatments in all 4 experiments (Fig. 6, Table 2).

\section{DISCUSSION}

In our experiments, no major increases in epiphyte biomass occurred, and no major loss of seagrass via algal overgrowth was observed, even though our nutrient loading rates were quite high (Table 5). Epiphyte and T. testudinum C:N, C:P, and N:P values were significantly lower in enriched than ambient treatments in a majority of the cases (Table 2). These lower $\mathrm{C}: \mathrm{N}$ and $\mathrm{C}: \mathrm{P}$ ratios indicate increased $\mathrm{N}$ and $\mathrm{P}$ in plant tissues, and a lower N:P ratio indicates an increased $\mathrm{P}$ in the tissues relative to $\mathrm{N}$, thus confirming that nutrient enrichment occurred and suggesting that $\mathrm{P}$ was limiting. Additionally, zeaxanthin, chl $a$, and chl $b$ concentrations were significantly higher in enriched than in ambient treatments in a majority of cases (Table 2), also indicating that elevated nutrient loading occurred in the enriched treatments. We did not, however, see differences in the relative abundance of algal pigments, and thus algal species compo-
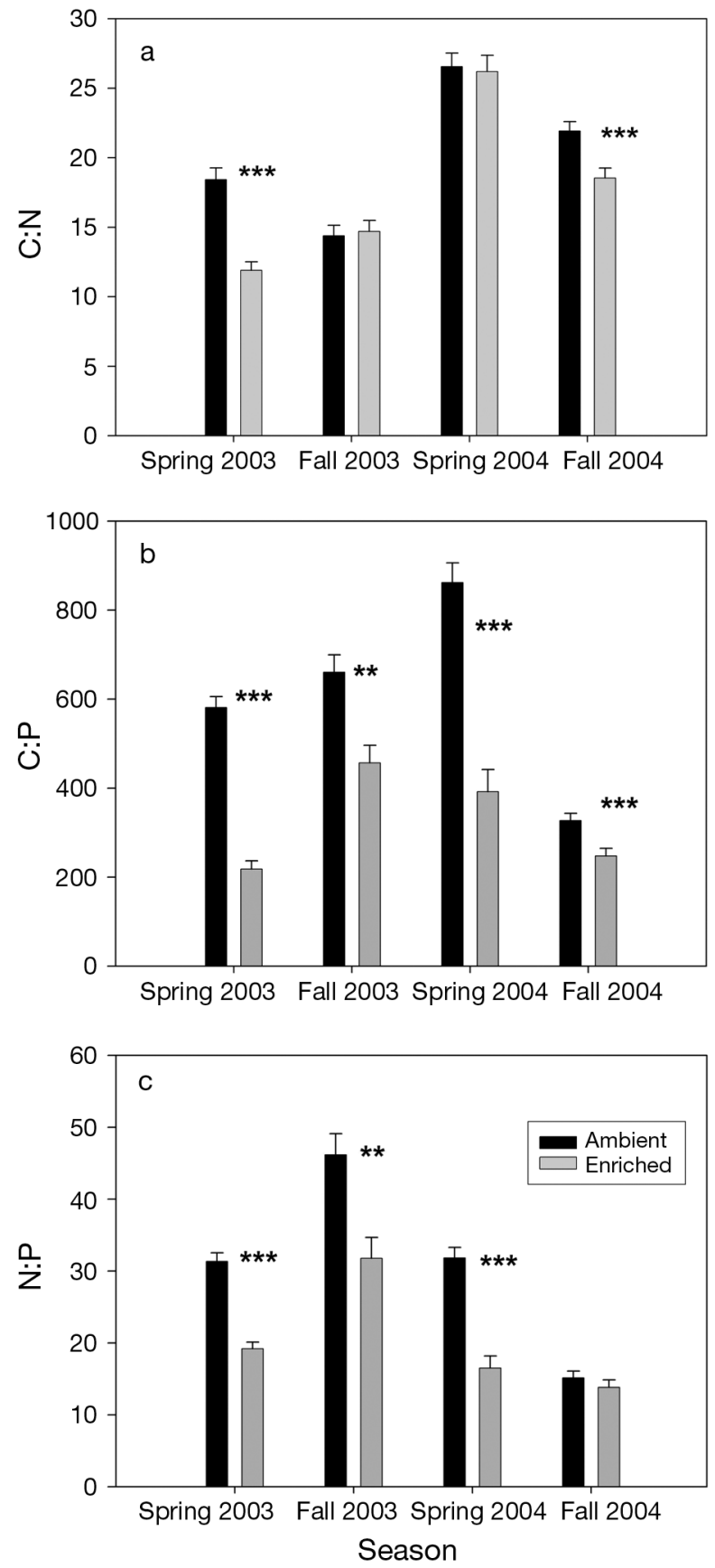

Fig. 4. Nutrient effects on epiphyte (a) $\mathrm{C}: \mathrm{N}$, (b) $\mathrm{C}: \mathrm{P}$, and (c) $\mathrm{N}: \mathrm{P}($ mean $\pm \mathrm{SE})$. Asterisks denote significant effect $\left({ }^{*} \mathrm{p} \leq\right.$ $0.05, * * \mathrm{p} \leq 0.01, * * * \mathrm{p} \leq 0.001)$ 

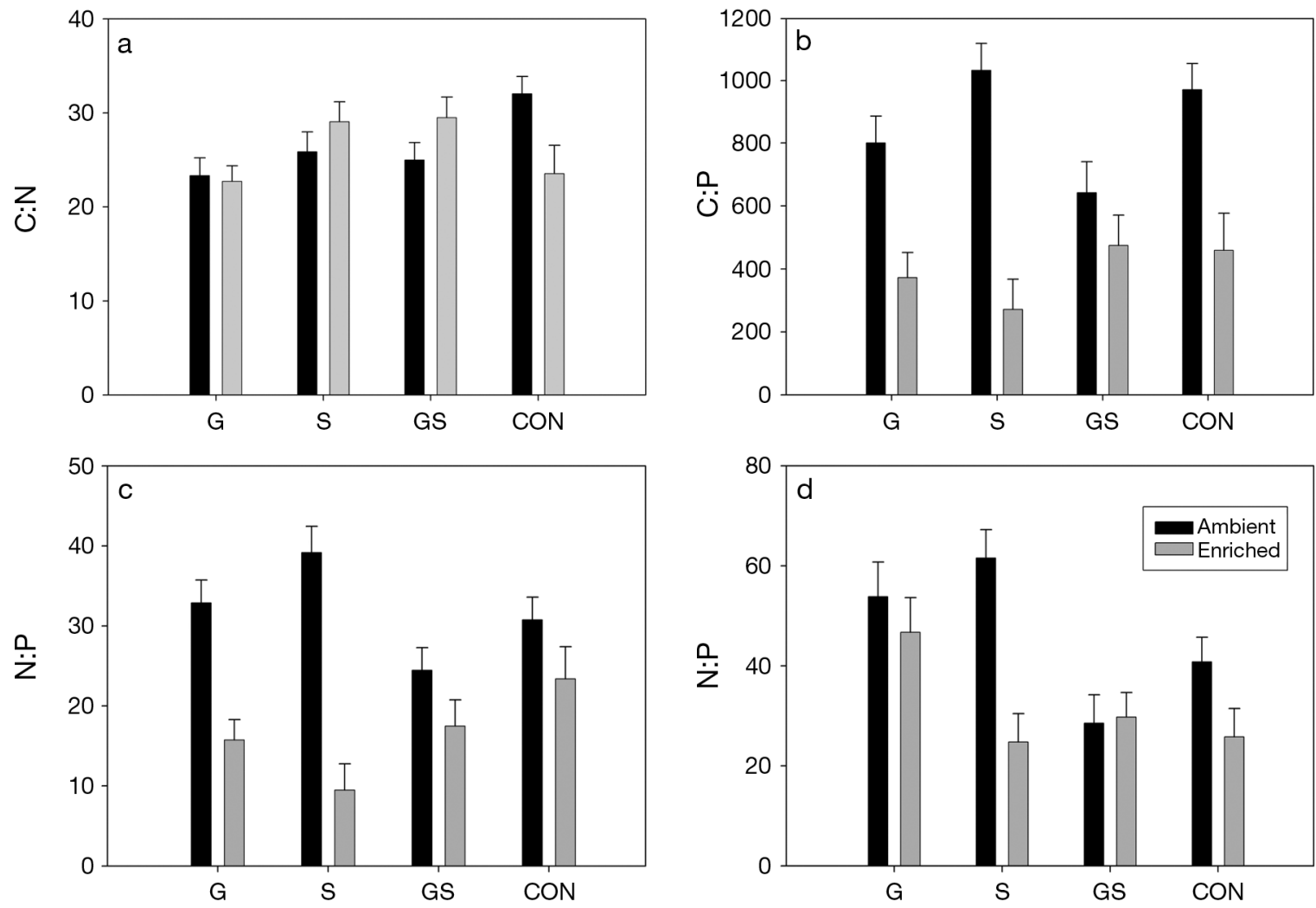

Grazer treatment

Fig. 5. Combined effects of nutrients and grazers on (a) spring 2004 epiphyte C:N, (b) spring 2004 epiphyte C:P, (c) spring 2004 epiphyte N:P, and (d) fall 2003 epiphyte N:P. Grazer abbreviations are as in Fig. 3

Table 5. Comparison of estimated nitrogen and phosphorus loading rates in this study with those of previous experimental manipulations in seagrass systems and estuaries for which data exist. This table is modified from Heck et al. (2006)

\begin{tabular}{|c|c|c|}
\hline & $\begin{array}{c}\text { N-loading } \\
\left(\mathrm{mmol} \mathrm{m}^{-2} \mathrm{~d}^{-1}\right)\end{array}$ & $\begin{array}{c}\text { P-loading } \\
\left(\mathrm{mmol} \mathrm{m}^{-2} \mathrm{~d}^{-1}\right)\end{array}$ \\
\hline \multicolumn{3}{|l|}{ Field manipulations } \\
\hline This study & $282-949$ & $41-142$ \\
\hline Heck et al. $(2006)^{a}$ & $576-886$ & $35-54$ \\
\hline Heck et al. $(2000)^{a}$ & $77-123$ & $5-7$ \\
\hline McGlathery (1995) & 300 & 34.5 \\
\hline Williams \& Ruckelshaus $(1993)^{\text {b }}$ & $476-510$ & \\
\hline \multicolumn{3}{|l|}{ Estuaries } \\
\hline Chesapeake Bay $^{\mathrm{c}}$ & 1.9 & 0.11 \\
\hline Delaware Bayc & 19.2 & 1.6 \\
\hline Florida Bay ${ }^{\mathrm{d}}$ & 0.0997 & 0.00329 \\
\hline Narragansett Bay ${ }^{c}$ & 2.7 & 0.22 \\
\hline Thames Estuary, UK ${ }^{\mathrm{c}}$ & 87.7 & 8.7 \\
\hline \multicolumn{3}{|c|}{$\begin{array}{l}\text { a Dissolved inorganic nitrogen (DIN) added as } \mathrm{NO}_{3} \text { and } \mathrm{NH}_{4}{ }^{b} \mathrm{DIN} \text { added as } \\
\mathrm{NH}_{4} \text { only; }{ }^{\mathrm{c}} \text { Estimated from Nixon et al. (1986); }{ }^{\mathrm{d}} \text { Estimated from Rudnick et } \\
\text { al. (1999) }\end{array}$} \\
\hline
\end{tabular}

sition, with the addition of nutrients. In all experiments, chl a was the most abundant pigment in both ambient and enriched treatments, which was expected since chl $a$ is found in virtually all algal groups. Zeaxanthin was the least abundant pigment in both ambient and enriched treatments in all experiments, indicating that the cyanobacterial dominance that often occurs during nutrient enrichment (Paerl et al. 2003, Armitage \& Fong 2004) did not occur in our experiments.

Nutrient loading rates in our study ranged from 281 to $949 \mathrm{mmol} \mathrm{m}^{-2} \mathrm{~d}^{-1}$ for nitrogen and from 41 to $141 \mathrm{mmol}$ $\mathrm{m}^{-2} \mathrm{~d}^{-1}$ for phosphorus. Our $\mathrm{N}$ and $\mathrm{P}$ loading rates are much greater than those reported for eutrophic estuaries such as Chesapeake Bay, Delaware Bay, and the Thames Estuary, as has been the case with other nutrient 
enrichment experiments (see Table 5). Both ambient and enriched Thalassia testudinum $\mathrm{C}: \mathrm{N}$ ratios achieved in this experiment were comparable to those obtained by McGlathery (1995) and Heck et al. (2006), and ambient and enriched N:P ratios were slightly greater than those reported by McGlathery (1995). Ambient and enriched C:P ratios were comparable to
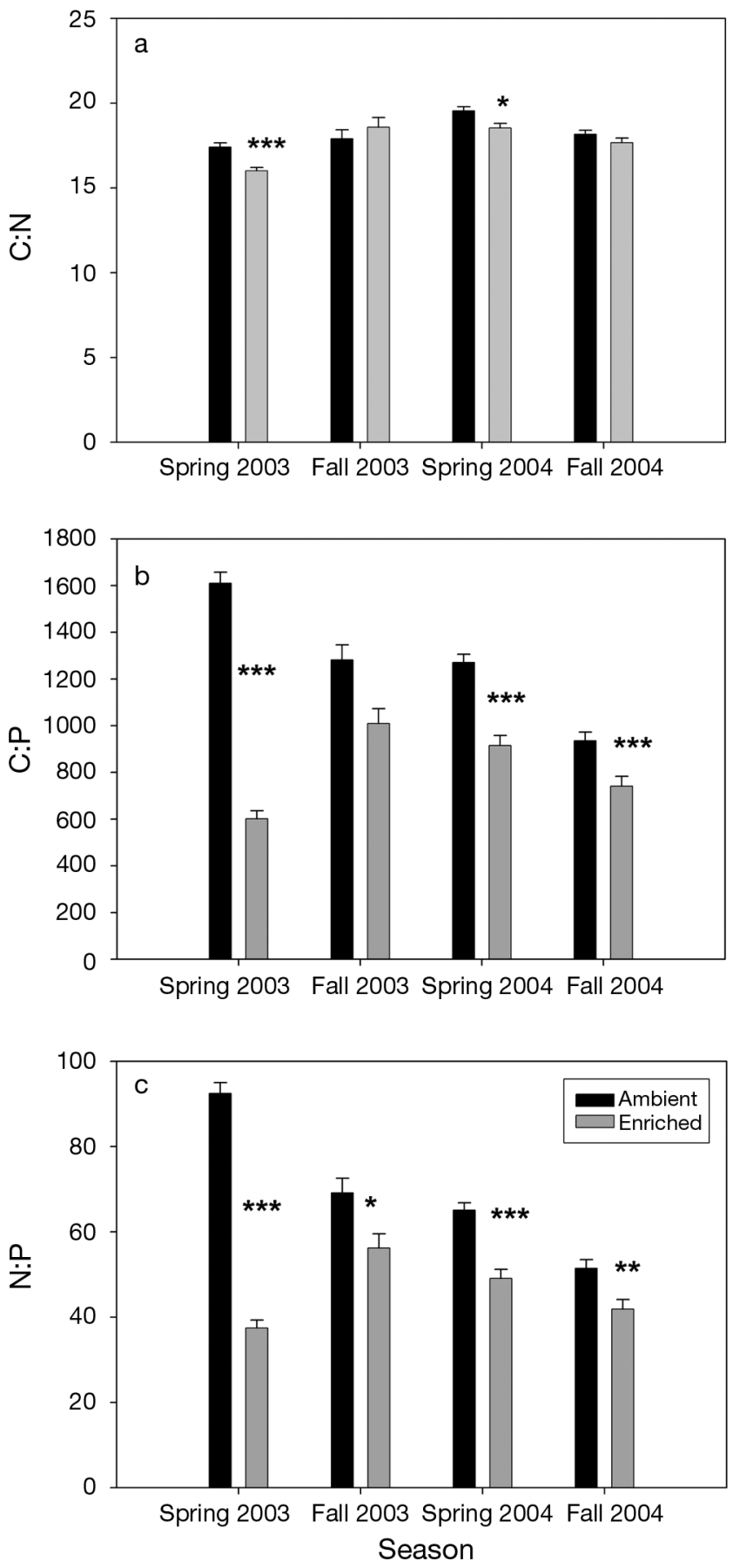

Fig. 6. Nutrient effects on Thalassia testudinum (a) C:N, (b) $\mathrm{C}: \mathrm{P}$, and (c) $\mathrm{N}: \mathrm{P}$ (mean $\pm \mathrm{SE}$ ). Asterisks denote significant effect $(* p \leq 0.05, * * p \leq 0.01, * * * p \leq 0.001)$ those reported by Heck et al. (2006) and much greater than those reported by McGlathery (1995). Both ambient and enriched $\mathrm{C}: \mathrm{N}, \mathrm{C}: \mathrm{P}$, and $\mathrm{N}: \mathrm{P}$ values for T. testudinum leaves obtained during our experiments are within the range reported across Florida Bay by Fourqurean et al. (1992) and Armitage et al. (2005); however, ambient C:P and N:P were much higher than the mean T. testudinum $\mathrm{C}: \mathrm{P}$ and N:P for Florida Bay, while ambient $\mathrm{C}: \mathrm{N}$ was roughly equal to the mean $\mathrm{C}: \mathrm{N}$ for $T$. testudinum in Florida Bay as reported by Fourqurean et al. (1992). This, in combination with the fact that nutrient enrichment significantly decreased both epiphyte and T. testudinum C:P and N:P in all but 2 cases (fall 2003 T. testudinum C:P and fall 2004 epiphyte $\mathrm{N}: \mathrm{P}$ ), whereas epiphyte and $T$. testudinum $\mathrm{C}: \mathrm{N}$ significantly decreased only in response to nutrient enrichment in half the cases, confirms conclusions by earlier investigators (e.g. Fourqurean \& Zieman 2002, Armitage et al. 2005) that $\mathrm{P}$ is more often limiting than $\mathrm{N}$ at our study sites.

Trends in the effects of grazers on the measured parameters were not clear, and our experiments did not produce the strong grazer effects that have been documented in many other studies. Moreover, we found very few significant nutrient-grazer interactions. One interpretation of these results is that there may be no important differential response to nutrients by individual grazer species, and that varying species combinations of grazers did not produce differential effects. Although our study used grazers with different feeding morphologies, i.e. gastropods with less selective, rasping feeding and caridean shrimp and hermit crabs with the ability to be more selective, it is possible that these different feeding styles were equally efficient in removing epiphyte biomass, leading to no one grazer or combination of grazers having significantly different effects; however, this interpretation is complicated by the fact that epiphyte biomass in grazer treatments was not significantly different from the control treatment.

The lack of difference between the control and grazer treatments could be explained by the unwanted amphipods in 29 out of 31 control treatments, whose numbers ranged from 4 to 182 and averaged 33 per control cylinder (a density of $471 \mathrm{~m}^{-2}$ ). It is possible that grazing by the unwanted amphipods in the control cylinders lowered epiphyte biomass to the same low level that the experimental grazers did, thus effectively doing away with the control treatment and making all treatments grazer treatments. This argument is strengthened by the lack of significant effects when amphipods were included as a covariate in the statistical models. In other words, the effects on epiphyte biomass (and epiphyte algal pigment concentrations and epiphyte C:N:P) were not different from those caused by the experimental grazers. 
To determine if this explanation was feasible, we estimated the amount of leaf surface area in our experimental cylinders and applied epiphyte production rates and amphipod feeding rates from the literature. Using the leaf surface area measurements taken from the epiphyte biomass determinations (see 'Materials and methods' section), we calculated that the average individual leaf surface area over the 4 experiments was $9.41 \mathrm{~cm}^{2}$. From our measurements of Thalassia testudinum aboveground biomass (see 'Materials and methods' section), we determined that the average number of leaves per cylinder over the 4 experiments was 136 leaves cylinder ${ }^{-1}$ by taking the average number of blades per core sample and extrapolating this number to the area of the cylinder. Multiplying the average number of leaves per cylinder (136) times the average individual leaf surface area $\left(9.41 \mathrm{~cm}^{2}\right)$ results in an average leaf surface area of $1279.76 \mathrm{~cm}^{2}$ cylinder ${ }^{-1}$. Using data obtained from Florida Coastal Everglades Long Term Ecological Research (FCE LTER) sites in Florida Bay that were located near our study sites at Bob Allen Keys and Peterson Key (Gaiser 2008), we calculated the average periphyton productivity near our sites during our experiments. To determine the average periphyton productivity near Bob Allen Keys during our spring experiments, we averaged the average periphyton productivity values at the Bob Allen Keys LTER site from June 2003 (0.019 $\mathrm{mg} \mathrm{DW} \mathrm{cm}^{-2} \mathrm{~d}^{-1}$ ) with the average periphyton productivity values from May 2004 (0.069 mg DW cm $\mathrm{cm}^{-1}$ ) and estimated that the average productivity of periphyton near Bob Allen Keys for spring 2003 and 2004 was $0.04 \mathrm{mg}$ DW $\mathrm{cm}^{-2} \mathrm{~d}^{-1}$. To determine the average periphyton productivity near Peterson Key during our fall experiments, we averaged the average periphyton productivity values at the Sprigger Bank LTER site from October 2003 (0.020 mg DW $\mathrm{cm}^{-2} \mathrm{~d}^{-1}$ ) with the average periphyton productivity values from October 2004 (0.036 mg DW $\mathrm{cm}^{-2} \mathrm{~d}^{-1}$ ) and estimated that the average productivity of periphyton near Peterson Key for fall 2003 and 2004 was $0.03 \mathrm{mg} \mathrm{DW} \mathrm{cm}^{-2} \mathrm{~d}^{-1}$ (Gaiser 2008). These values were then applied to our estimates of average leaf surface area cylinder ${ }^{-1}$ to obtain an average productivity of $51.19 \mathrm{mg}$ periphyton cylinder ${ }^{-1} \mathrm{~d}^{-1}$ during spring experiments and $38.39 \mathrm{mg}$ periphyton cylinder $\mathrm{r}^{-1} \mathrm{~d}^{-1}$ during fall experiments.

To estimate feeding rates of amphipods, we averaged the feeding rates of Ampithoe longimana on various types of brown, green, and red algae in no-choice feeding experiments from Cruz-Riviera \& Hay (2001). This average was $6.25 \mathrm{mg}$ wet wt ind. ${ }^{-1} \mathrm{~d}^{-1}$, and after applying a wet wt to dry wt conversion ratio of 0.22 (Leal et al. 1997), the average feeding rate was
$1.375 \mathrm{mg}$ DW ind. ${ }^{-1} \mathrm{~d}^{-1}$. Multiplying by the average number of 33 unwanted amphipods cylinder ${ }^{-1}$ found in the control cylinders, we obtained an average feeding rate of $45 \mathrm{mg}$ periphyton $\mathrm{d}^{-1}$ cylinder ${ }^{-1}$. When compared to the average periphyton productivity of $51.19 \mathrm{mg}$ cylinder ${ }^{-1} \mathrm{~d}^{-1}$ during the spring and $38.39 \mathrm{mg}$ cylinder ${ }^{-1} \mathrm{~d}^{-1}$ during the fall, the amphipods were theoretically capable of keeping epiphyte biomass levels low during the fall experiments and were very close to doing so in the spring experiments.

Although we succeeded in enriching our experimental cylinders, we did not observe major increases in epiphyte biomass or major loss of Thalassia testudinum by algal overgrowth. Additionally, we did not see any strong grazer effects and very few significant nutrientgrazer interactions, and our results were complicated by the lack of significant differences between control and grazer treatments. If our theory that these results were caused by the presence of unwanted amphipod grazers in our experimental cylinders is true, then the effects of invertebrate grazing are stronger than the effects of nutrient enrichment on epiphytic algae, and relatively low densities of amphipod grazers can control epiphyte biomass even in the face of highly elevated nutrient loading rates. This study underscores the need for additional efforts to better elucidate the roles of different types of invertebrate grazers in the food webs of eutrophic coastal ecosystems, and to estimate the relative importance of top-down and bottom-up effects in different types of human-influenced coastal ecosystems.

Acknowledgements. This research was made possible by grants from the Alabama Center for Estuarine Studies (ACES Project \# R-83065101-3-05), the Everglades National Park (ENP) under cooperative agreement 1443CA528001022, and the Florida Coastal Everglades Long Term Ecological Research (LTER) Program funded by the US National Science Foundation (Cooperative Agreement \# DEB-9910514). D. Morrison and B. Perry facilitated permit issuance and the use of ENP facilities. Periphyton loading data sets were provided by the Florida Coastal Everglades Long Term Ecological Research (LTER) Program. Significant funding for the collection of these data was provided by the National Science Foundation Long Term Ecological Research Program (NSF grant numbers BSR-90-11663 and DEB-96-32921). This material is based upon work supported by the National Science Foundation under Grant \# 9910514. The authors thank the following people for their hard work and assistance with the field experiments: R. Adams, D. Booth, D. Byron, B. Furman, J. Koeppel, L. Krammer, K. Merkins, R. Shiplett, T. Spitzer, C. Steeves, and K. Young from the Dauphin Island Sea Laboratory, and B. Dewsbury, C. Furst, M. Gil, S. Ruiz, T. Thyberg, and P. William from Florida International University. We also thank J. Zieman for the use of University of Virginia boats and housing and D. Smith of the National Park Service for supplying us with data on water levels in Florida Bay. This is contribution number 399 from the Dauphin Island Sea Lab and 480 from the Southeast Environmental Research Center at Florida International University. 


\section{LITERATURE CITED}

Armitage AR, Fong P (2004) Upward cascading effects of nutrients: shifts in a benthic microalgal community and a negative herbivore response. Oecologia 139:560-567

Armitage AR, Frankovich TA, Heck KL, Fourqurean JW (2005) Experimental nutrient enrichment causes complex changes in seagrass, microalgae, and macroalgae community structure in Florida Bay. Estuaries 28:422-434

Armitage AR, Frankovich TA, Fourqurean JW (2006) Variable responses within epiphytic and benthic microalgal communities to nutrient enrichment. Hydrobiologia 569: 423-435

Burkepile DE, Hay ME (2006) Herbivore vs. nutrient control of marine primary producers: context-dependent effects. Ecology 87:3128-3139

Burkholder JM, Tomasko DA, Touchette BW (2007) Seagrasses and eutrophication. J Exp Mar Biol Ecol 350:46-72

Capone DG, Penhale PA, Oremland RS, Taylor BF (1979) Relationship between productivity and $\mathrm{N}_{2}\left(\mathrm{C}_{2} \mathrm{H}_{2}\right)$ fixation in a Thalassia testudinum community. Limnol Oceanogr 24:117-125

> Caraco NF, Cole JJ, Raymond PA, Strayer DL, Pace ML, Findlay SEG, Fischer DT (1997) Zebra mussel invasion in a large, turbid river: phytoplankton response to increased grazing. Ecology 78:588-602

> Cruz-Rivera E, Hay ME (2001) Macroalgal traits and the feeding and fitness of an herbivorous amphipod: the roles of selectivity, mixing, and compensation. Mar Ecol Prog Ser 218:249-266

> Doty MS (1971) Measurement of water movement in reference to benthic algal growth. Bot Mar 14:32-35

Duarte CM (1995) Submerged aquatic vegetation in relation to different nutrient regimes. Ophelia 41:87-112

> Duffy JE (1990) Amphipods on seaweeds: partners or pests? Oecologia 83:267-276

> Duffy JE, Harvilicz AM (2001) Species-specific impacts of grazing amphipods in an eelgrass-bed community. Mar Ecol Prog Ser 223:201-211

Duffy JE, Hay ME (2000) Strong impacts of grazing amphipods on the organization of a benthic community. Ecol Monogr 70:237-263

Fong CW, Lee SY, Wu RSS (2000) The effects of epiphytic algae and their grazers on the intertidal seagrass Zostera japonica. Aquat Bot 67:251-261

Fourqurean JW, Robblee MB (1999) Florida Bay: a history of recent ecological changes. Estuaries 22:345-357

> Fourqurean JW, Zieman JC (2002) Nutrient content of the seagrass Thalassia testudinum reveals regional patterns of relative availability of nitrogen and phosphorus in the Florida Keys USA. Biogeochemistry 61:229-245

Fourqurean JW, Zieman JC, Powell GVN (1992) Phosphorous limitation of primary production in Florida Bay: evidence from C:N:P ratios of the dominant seagrass Thalassia testudinum. Limnol Oceanogr 37:162-171

Frankovich TA, Zieman JC (2005) A temporal investigation of grazer dynamics, nutrients, seagrass leaf productivity, and epiphyte standing stock. Estuaries 28:41-52

Gacia E, Littler MM, Littler DS (1999) An experimental test of the capacity of food web interactions (fish-epiphyteseagrasses) to offset the negative consequences of eutrophication on seagrass communities. Estuar Coast Shelf Sci 48:757-766

Gaiser E (2008) Periphyton accumulation rates from the Shark River Slough and Taylor River Slough, Everglades National Park, from January 2001 to February 2008: longterm ecological research. Florida Coastal Everglades
Data Set ST_PP_Gaiser_001.v4.http://fcelter.fiu.edu/data/ core/metadata/? datasetid=ST_PP_Gaiser_001.v4 (Accessed April 14, 2008)

Gil M, Armitage AR, Fourqurean JW (2006) Nutrient impacts on epifaunal density and species composition in a subtropical seagrass bed. Hydrobiologia 569:437-447

Hauxwell J, Cebrian J, Furlong C, Valiela I (2001) Macroalgal canopies contribute to eelgrass (Zostera marina) decline in temperate estuarine ecosystems. Ecology 82:1007-1022

Heck KL, Valentine JF (2007) The primacy of top-down effects in shallow benthic ecosystems. Estuar Coast 30: 371-381

Heck KL, Pennock JR, Valentine JF, Coen LD, Sklenar SA (2000) Effects of nutrient enrichment on small predator density on seagrass ecosystems: an experimental assessment. Limnol Oceanogr 45:1041-1057

Heck KL Jr, Valentine JF, Pennock JR, Chaplin G, Spitzer PM (2006) Effects of nutrient enrichment and grazing on shoalgrass (Halodule wrightii) and its epiphytes: results of a field experiment. Mar Ecol Prog Ser 326:145-156

Holmquist JG, Powell GVN, Sogard SM (1989) Sediment, water level and water temperature characteristics of Florida Bay's grass-covered mud banks. Bull Mar Sci 44: 348-364

> Hootsmans MJM, Vermaat JE (1985) The effect of periphyton-grazing by three epifaunal species on the growth of Zostera marina L. under experimental conditions. Aquat Bot 22:83-88

> Howard RK (1982) Impact of feeding activities of epibenthic amphipods on surface-fouling of eelgrass leaves. Aquat Bot 14:91-97

> Howard RK, Short FT (1986) Seagrass growth and survivorship under the influence of epiphyte grazers. Aquat Bot 24:287-302

Hughes RA, Bando KJ, Rodriguez LF, Williams SL (2004) Relative effects of grazers and nutrients on seagrasses: a meta-analysis approach. Mar Ecol Prog Ser 282:87-99

Jeffrey SW, Mantoura RFC, Wright SW (eds) (1997) Phytoplankton pigments in oceanography: guidelines to modern methods. UNESCO, Paris

Jernakoff P, Nielsen J (1997) The relative importance of amphipod and gastropod grazers in Posidonia sinuosa meadows. Aquat Bot 56:183-202

Leal MCF, Vasconcelos MT, Sousa-Pinto I, Cabral JPS (1997) Biomonitoring with benthic macroalgae and direct assay of heavy metals in seawater of the Oporto Coast (Northwest Portugal). Mar Pollut Bull 34:1006-1015

McGlathery KJ (1995) Nutrient and grazing influences on a subtropical seagrass community. Mar Ecol Prog Ser 122: 239-252

Nielsen KJ (2003) Nutrient loading and consumers: agents of change in open-coast macrophyte assemblages. Proc Natl Acad Sci USA 100:7660-7665

Nixon SW, Oviatt C, Frithsen J, Sullivan B (1986) Nutrients and productivity of estuaries and coastal marine ecosystems. J Limnol Soc S Afr 12:43-71

Officer CB, Smayda TJ, Mann R (1982) Benthic filter feeding: a natural eutrophication control. Mar Ecol Prog Ser 9: 203-210

Orth RJ, van Montfrans J (1987) Utilization of a seagrass meadow and tidal marsh creek by blue crabs Callinectes sapidus. 1. Seasonal and annual variations in abundance with emphasis on post-settlement juveniles. Mar Ecol Prog Ser 41:283-294

Orth RJ, Carruthers TJB, Dennison WC, Duarte CM and others (2006) A global crisis for seagrass ecosystems. Bioscience 56:987-996 
Paerl HW, Valdes LM, Pinckney JL, Piehler MF, Dyble J, Moisander PH (2003) Phytoplankton photopigments as indicators of estuarine and coastal eutrophication. Bioscience 53:953-964

Peterson BJ, Fourqurean JW (2001) Large-scale patterns in seagrass (Thalassia testudinum) demographics in south Florida. Limnol Oceanogr 46:1077-1090

Philippart CJM (1995) Effect of periphyton grazing by Hydrobia ulvae on the growth of Zostera noltii on a tidal flat in the Dutch Wadden Sea. Mar Biol 122:431-437

Robblee MB, Daniels A (2003) Fish and shrimp in relation to seagrass habitat change in Johnson Key Basin, western Florida Bay (1985-1995). In: Joint Conference on the Science and Restoration of the Greater Everglades and Florida Bay Ecosystem. National Oceanographic and Atmospheric Administration, Miami, FL, p 230-232

Rudnick DT, Chen Z, Childers DL, Boyer JN, Fontaine DL (1999) Phosphorus and nitrogen inputs to Florida Bay: the importance of the Everglades watershed. Estuaries 22: 398-416

Ruesink JL (2000) Intertidal mesograzers in field microcosms: linking laboratory feeding rates to community dynamics. J Exp Mar Biol Ecol 248:163-176

Editorial responsibility: Just Cebrian, Dauphin Island, Alabama, USA
Sharp JH (1974) Improved analysis for 'particulate' organic carbon and nitrogen from seawater. Limnol Oceanogr 19: 984-989

Solórzano L, Sharp JH (1980) Determination of total dissolved phosphorus and particulate phosphorus in natural waters. Limnol Oceanogr 25:754-758

Turney WJ, Perkins BF (1972) Molluscan distribution in Florida Bay. Sedimenta III. Rosential School of Marine Sciences, University of Miami, Florida

van Montfrans J, Orth RJ, Vay SA (1982) Preliminary studies of grazing by Bittium varium on eelgrass periphyton. Aquat Bot 14:75-89

Waycott M, Duarte CM, Carruthers TJB, Orth RJ and others (2009) Accelerating loss of seagrasses across the globe threatens coastal ecosystems. Proc Natl Acad Sci USA 106:12377-12381

Williams SL, Ruckelshaus MH (1993) Effects of nitrogen availability and herbivory on eelgrass (Zostera marina) and epiphytes. Ecology 74:904-918

Wright SW, Jeffrey SW, Mantoura RFC, Llewellyn CA, Bjoernland T, Repeta D, Welschmeyer N (1991) Improved HPLC method for the analysis of chlorophylls and carotenoids from marine phytoplankton. Mar Ecol Prog Ser 77: 183-196

Submitted: November 8, 2007; Accepted: February 5, 2010 Proofs received from author(s): April 26, 2010 